B-Sitosterol. $\mathrm{C}_{29} \mathrm{H}_{50} \mathrm{O}$ (found: $\mathrm{C}, 83.98 ; \mathrm{H}, 12.15$; required: $\mathrm{C}, 84.05 ; \mathrm{H}, 12 \cdot 07$, IR, NMR, m/e $414\left(\mathrm{M}^{+}\right)$. [a] $]_{\mathrm{D}}$, m.p., mixed m.p., of sterol and its acetate). From benzene$\mathrm{CHCl}_{3}$ fractions and crystallizations with acetone. Alcoholic extract was extracted with $\mathrm{Et}_{2} \mathrm{O}$. Extract on repeated crystallizations with $\mathrm{EtOH}$ gave ursolic acid. $\mathrm{C}_{\mathbf{3 0}} \mathrm{H}_{\mathbf{4}} \mathrm{O}_{\mathbf{3}}$ (found: $\mathrm{C}, 78.80 ; \mathrm{H}, 10.58$; required: $\mathrm{C}, 78.94, \mathrm{H}, 10.52$, m.p., mixed m.p., [a] $]_{\mathrm{D}}, \mathrm{m} / \mathrm{e} 456\left(\mathrm{M}^{+}\right)$; co-TLC, m.p., methyl ester and formate).

Glucose, fructose and sucrose have been identified in the aq. solution by paper chromatography.

Phytochemistry, 1971, Vol. 10, pp. 3319 to 3320. Pergamon Press. Printed in England.

\title{
PHYTOLACCACEAE
}

\section{3-ACETYLOLEANOLIC ACID FROM PHYTOLACCA AMERICANA SEEDS*}

\author{
D. E. BURKe and P. W. LE QUESNE \\ Department of Chemistry, University of Michigan, Ann Arbor, Mich. 48104, U.S.A.
}

(Received 28 May 1971)

\begin{abstract}
Acetyloleanolic acid has been obtained from the seeds of Phytolacca americana L. It has not been detected in other parts of the plant. Oleanolic acid has been detected in the roots.

\section{INTRODUCTION}

THE ROOTs of Phytolacca americana, abundant in the eastern United States, owe their toxicity to phytolaccatoxin, a disaccharide (xylose, glucose) of phytolaccagenin (I). ${ }^{1}$ Since phytolaccagenin probably arises biogenetically from oleanolic acid (II), we have searched for related compounds in the plant which might reflect aspects of this conversion.
\end{abstract}

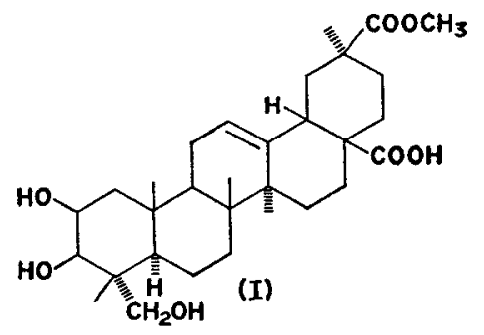

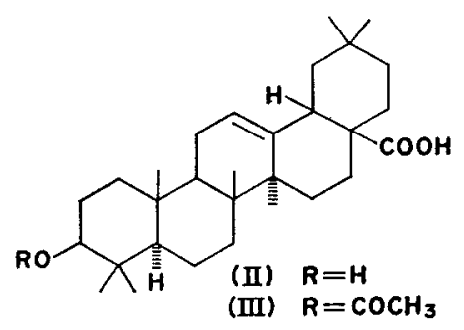

\section{RESULTS}

Light petroleum extraction of the seeds of $P$. americana gave oily material from which 3-acetyloleanolic acid (III) was obtained in 0.17 per cent yield. The seeds were further extracted with methanol. No other triterpenoids were detected in either extract.

1 G. H. Stout, B. M. Malofsky and V. F. Stout, J. Am. Chem. Soc. 86, 957 (1964). 
An extraction of the roots yielded, as free triterpenoids, traces of oleanolic acid (II) and phytolaccagenin (I), detected chromatographically. No other triterpenes were detected. It is possible that the phytolaccagenin arises by hydrolysis of phytolaccatoxin during preparation of the plant material. The juice of mature berries of $P$. americana foams on shaking with water, but acid hydrolysis of freeze-dried juice gave no detectable triterpenoids.

These results suggest that phytolaccagenın (I) arises in vivo by hydroxylation of oleanolic acid (II); the occurrence of (III) as the only other triterpenoid detected suggests that acetylation of the C-3-hydroxyl group may block the further hydroxylation leading to phytolaccagenin.

\title{
EXPERIMENTAL
}

Extraction of $\mathrm{P}$. americana seeds. The finely-ground seeds $(650 \mathrm{~g})$ were extracted (Soxhlet) with petroleum ether (b.p. $30-60^{\circ}$ ) for $30 \mathrm{hr}$. Concentration of the extract gave a yellow oll, which durng $24 \mathrm{hr}$ deposited fine needles $(1 \cdot 1 \mathrm{~g})$ m.p. $290-300^{\circ}$. Recrystallization once from EtOAc-EtOH gave pure 3-acetyloleanolıc acid, m.p. $290-300^{\circ}$ identified by IR, NMR, and mass spectra, ${ }^{2}$ and preparation of oleanolic acid (hydrolysis), methyl oleanolate (hydrolysis and methylation with $\mathrm{CH}_{2} \mathrm{~N}_{2}$ ), and methyl 3-acetyloleanolate (methylation with $\mathrm{CH}_{2} \mathrm{~N}_{2}$ ). The physical constants of these three derivatives were in exact accord with the literature. ${ }^{3}$

Extraction of $\mathrm{P}$. americana roots. The dried, ground root $(70 \mathrm{~g})$ was extracted with petroleum ether (b.p. $30-60^{\circ}$ ) (Soxhlet) for $72 \mathrm{hr}$. The extract was concentrated and analysed by TLC, using Eastman Chromagram silica gel plates with toluene-EtOAc-HOAc $(12.4: 0 \cdot 5)^{4}$ and $\mathrm{SbCl}_{3}$ in $\mathrm{CHCl}_{3}$ as spray reagent. Phytolaccagenın and oleanolic acid were identified by co-chromatography against authentic samples. No other triterpenoids were detected by this method.

Extraction of $\mathrm{P}$. americana berry juce. The freeze-dried juce $(100 \mathrm{~g})$ was heated under reflux with $10 \%$ $\mathrm{HCl}$ in $\mathrm{MeOH}-\mathrm{H}_{2} \mathrm{O}(1: 4)(500 \mathrm{ml})$ for $10 \mathrm{hr}$. The mixture was partly neutralized with $\mathrm{NaHCO}_{3}$ and extracted with ether. The ether layer was decolorized (Norit), dried $\left(\mathrm{MgSO}_{4}\right)$ and concentrated to small volume. This was subjected to TLC as above. No triterpenords were detected.

Acknowledgements - We thank Dr. Arnold Krochmal, Northeastern Forest Experiment Station, U.S.D.A., Berea, Kentucky, for generous provision of plant material, and Professor George Stout for authentic samples of phytolaccatoxin. This work was supported by a research grant from the Horace $\mathrm{H}$. Rackham School of Graduate Studies, University of Michigan (to P. W. Le Q.) and by an N.S F Traineeship (to D.E.B.)

2 C. Djerassi, H. Budzikiewicz and J. M. WiLson, Tetrahedron Letters No. 7, 263 (1962).

${ }^{3}$ Les Triterpenoides en Physiologie Vegetale et Animale (edıted by P. BoIteaU, B. Pasich and A. Rakoto Ratsimamanga), p. 139, Gauthier-Villars, Paris (1964).

4 M. H. A. Elgamal and M. B. E. FAYAZ, Z. Analyt. Chem 211, 190 (1965).

Phytochemistry, 1971, Vol. 10, pp 3320 to 3322 Pergamon Press Printed in England

\section{RANUNCULACEAE}

\section{ALKALOIDS OF ACONITUM VIOLACEUM}

\author{
G. A. Miana, * M. Ikram, M. Israr Khan and F. Sultana \\ P.C.S.I.R. Laboratories, Peshawar, P.O. Pcshawar Untversity, Pakistan
}

(Received 8 April 1971)

Aconitum violaceum Jacq. is available in Azad Kashmir. The roots of the plant are reported to be poisonous according to some, non-poisonous according to others and are eaten by the hillmen of Kunwar as a pleasant tonic. ${ }^{1}$ Although, other Aconitum species, such as

* Present address: Institute of Chemistry, University of Islamabad, Islamabad, Pakistan.

1 R N. Chopra, S. L. Nayar and I. C. Chopra, Glossary of Indian Medicinal Plants, p. 5, Council of Scientific and Industrial Research, New Delhi (1956). 